\title{
Germination temperatures and treatments to overcome dormancy in Belamcanda chinensis seeds ${ }^{1}$
}

\author{
Girlânio Holanda da Silva², Lenise Santos Baldini², \\ Camila Aquino Tomaz ${ }^{3}$, Rubiana Falopa Rossi ${ }^{4}$, João Nakagawa ${ }^{2}$
}

\section{ABSTRACT}

Belamcanda chinensis is an ornamental plant cultivated as a medicinal herb in its countries of origin: China and Japan. It is propagated by rhizomes and seeds, but little is known on the optimal conditions for its germination. This study aimed to assess germination temperatures and treatments to overcome its seed dormancy. Two experiments were conducted: the first evaluated the effects of constant temperatures of $20^{\circ} \mathrm{C}$, $25{ }^{\circ} \mathrm{C}$ and $30{ }^{\circ} \mathrm{C}$ (in the dark) and $20-30{ }^{\circ} \mathrm{C}$ with light (8-h photoperiod), while the second one involved the removal of combinations from the seed tegument structure (with and without tegument), with pre-hydration at $7{ }^{\circ} \mathrm{C}, 30{ }^{\circ} \mathrm{C}$ or no pre-hydration, in addition to an extra treatment without tegument or pre-hydration. Alternating the temperature results in better effects on the variables evaluated, while, at constant temperatures, there is little or no germination. The removal of the outer tegument structure and from seeds pre-hydrated at $30{ }^{\circ} \mathrm{C}$ accelerates the germination process.

KEYWORDS: Seed dormancy; pre-hydration; tegument removal.

\section{INTRODUCTION}

Belamcanda chinensis (L.) DC, known as leopard lily, is a herbaceous Iridaceae species from China and Japan, cultivated as an ornamental plant in Brazil (Lorenzi \& Souza 2001). It is a medicinal herb, whose chemical components are used for drug production (Padua et al. 1999, Zhang et al. 2006 and 2016, Xin et al. 2015). Its flowering period occurs in January and February, with fruit maturation between April and June. The fruit is dry, capsular and loculicidal, containing four to six subglobous seeds measuring 4-5 $\mathrm{mm}$ in diameter (Vitali et al. 1995, Padua et al. 1999).

\section{RESUMO}

Temperaturas de germinação e tratamentos para superação de dormência em sementes de Belamcanda chinensis

Belamcanda chinensis é uma planta ornamental cultivada como erva medicinal em seus países de origem: China e Japão. É propagada por rizomas e sementes, mas pouco se sabe sobre as condições ideais para a sua germinação. Objetivou-se avaliar temperaturas de germinação e tratamentos para superar a dormência das sementes. Foram realizados dois experimentos, sendo que o primeiro avaliou os efeitos de temperaturas constantes de $20^{\circ} \mathrm{C}$, $25^{\circ} \mathrm{C}$ e $30^{\circ} \mathrm{C}$ (no escuro) e $20-30^{\circ} \mathrm{C}$ com luz (fotoperíodo de $8 \mathrm{~h}$ ), e o segundo envolveu a remoção de combinações da estrutura do tegumento das sementes (com e sem tegumento), com préhidratação a $7^{\circ} \mathrm{C}, 30^{\circ} \mathrm{C}$ ou sem pré-hidratação, além de tratamento adicional sem tegumento ou pré-hidratação. A alternância da temperatura resulta em melhores efeitos nas variáveis avaliadas, enquanto, para temperaturas constantes, há pouca ou nenhuma germinação. A remoção da estrutura do tegumento externo e das sementes pré-hidratadas a $30^{\circ} \mathrm{C}$ acelera o processo germinativo.

PALAVRAS-CHAVE: Dormência de sementes; pré-hidratação; remoção de tegumento.

B. chinensis plants can propagate by rhizome and seed division (Lorenzi \& Souza 2001). However, the ideal conditions for seed germination remain unknown and there are no procedural specifications for its germination test in the Rules for Seed Analysis (Brasil 2009), what hinders the possible commercialization of its seeds.

B. chinensis seeds exhibit a slow and uneven germination, indicating the presence of dormancy. As such, the few studies available in the literature discuss the conditions and procedures that express its maximum germination potential. Qin et al. (2000) studied the effects of temperature on $B$. chinensis germination and found a low germination rate, which

1. Manuscript received in Aug./2017 and accepted for publication in Nov./2017 (http://dx.doi.org/10.1590/1983-40632017v4749059).

2. Universidade Estadual Paulista "Júlio de Mesquita Filho", Faculdade de Ciências Agrárias, Botucatu, SP, Brasil.

E-mails: girlanio_holanda@hotmail.com, lenisebaldini@gmail.com, secdamv@fca.unesp.br.

3. Faculdade La Salle de Lucas de Rio Verde, Rio Verde, MT, Brasil.E-mail: caatomaz@hotmail.com.

4. Escola Técnica Estadual, Unidade Remota de Tapurah, Tapurah, MT, Brasil.E-mail: rubianarossi@hotmail.com. 
extended for long periods under constant temperatures $\left(15-25^{\circ} \mathrm{C}\right)$, while alternating temperatures $\left(15-30^{\circ} \mathrm{C}\right.$ and $20-30{ }^{\circ} \mathrm{C}$ ) resulted in $64 \%$ of germination.

To overcome $B$. chinensis seed dormancy, stratification (pre-cooling) at $5^{\circ} \mathrm{C}$ for 60 days allows germination in one month, while non-stratified seeds do not germinate (Padua et al. 1999).

Stratification is recommended at $5-10{ }^{\circ} \mathrm{C}$ for up to seven days for Freesia refracta and at $3-5^{\circ} \mathrm{C}$ for 21 days for Iris kaempferi, when dormant seeds are detected (Brasil 2009). Both species belong to the Iridaceae family.

Morphophysiological dormancy occurs in the seeds of some Iridaceae species (Baskin \& Baskin 2014) and is associated with a deformed or rudimentary embryo, which, after dispersal, needs to reach an adequate size for visible germination to take place, while physiological dormancy is caused by hormonal balance (Bewley et al. 2012). To overcome morphophysiological dormancy, the seeds of certain species require only warm $\left(\geq 15^{\circ} \mathrm{C}\right)$ or cold stratification $\left(0-10^{\circ} \mathrm{C}\right)$, while others need warm stratification followed by cold stratification or vice versa (Baskin \& Baskin 2014).

Given the reports found in the literature on the Iridaceae family, this study aimed to determine the best temperature conditions and treatments to overcome dormancy in B. chinensis seeds, considering tegument removal.

\section{MATERIAL AND METHODS}

The study included two experiments with B. chinensis seeds: one that evaluated germination temperatures (Experiment I) and another which assessed treatments to overcome dormancy (Experiment II). Seeds from dehiscent fruits were collected in 2013 for the Experiment I and in 2014 for the Experiment II.

For the Experiment I, the germination test was conducted with four repetitions of 50 seeds, between sheets of germitest paper moistened with distilled water at a ratio of 2.5 times the weight of non-hydrated paper manufactured in rolls. They were placed in sealed plastic bags and kept in BOD germinators regulated at constant temperatures of $20^{\circ} \mathrm{C}, 25{ }^{\circ} \mathrm{C}$ and $30^{\circ} \mathrm{C}$, in the dark, alternating between $20^{\circ} \mathrm{C}$ and $30^{\circ} \mathrm{C}$, with an 8-h photoperiod (Brasil 2009). Counting occurred weekly, considering the primary root emission ( $\geq 2 \mathrm{~mm}$ ) and formation of a normal seedling (germination) for 17 weeks, after which the data showed no further changes. The seeds from constant temperature treatments, which were hydrated, nongerminated and exhibited no apparent contamination by microorganisms, were transferred to the germinator at alternating temperatures $\left(20-30{ }^{\circ} \mathrm{C}\right)$ to determine whether they would germinate. Weekly counts after transfering proceeded for 19 more weeks, until the data no longer changed. Finally, abnormal seedlings and non-germinated or dead seeds were assessed (Brasil 2009). In addition to the weekly counts, the percentages of root emission, germination, abnormal seedlings, non-germinated or dead seeds, speed indices (Maguire 1962) and average primary root emission and germination times (Santana \& Ranal 2000) were calculated, considering the interval in weeks.

The results were statistically analyzed in two phases: in the first, the germination test data obtained at different temperatures in the first 17 weeks were compared; in the second, data from constant temperature treatments, obtained after being transferred to alternating temperatures, were compared with the data from treatments where temperatures were maintained between $20{ }^{\circ} \mathrm{C}$ and $30{ }^{\circ} \mathrm{C}$ for the entire test. Analyses of variance were conducted using a random design, the data of all the variables expressed in percentage were transformed into $\mathrm{y}=\operatorname{arcsen}(x / 100)^{1 / 2}$ and those equal to zero into $y=(x+0.5)^{1 / 2}$ (Pimentel-Gomes 2000). The means were compared using the Tukey test at $5 \%$.

For the Experiment II, seeds with tegument were pure and whole. Seeds without the outer tegument structure were obtained by manual removal of the easily detachable bright black structure. The seeds without a tegument (naked) were obtained by manual removal of the outer tegument structure, followed by scraping the inner dark grey opaque structure attached to the endosperm with a razor blade. Pre-hydration was conducted for three weeks in moist substrate on germitest paper, forming rolls, similarly to the germination test.

The seeds were submitted to the following treatments: a) seeds with a tegument, pre-hydrated at $7{ }^{\circ} \mathrm{C}$; b) seeds with no outer tegument structure, pre-hydrated at $7{ }^{\circ} \mathrm{C}$; c) seeds with a tegument, prehydrated at $30{ }^{\circ} \mathrm{C}$; d) seeds with no outer tegument structure, pre-hydrated at $30{ }^{\circ} \mathrm{C}$; e) seeds with a tegument, without pre-hydration; f) seeds with no outer tegument structure, without pre-hydration; g) naked seeds, without pre-hydration. 
The germination test was conducted with four replications of 25 seeds and the remaining procedures were similar to those described in the Experiment I. In pre-hydration treatments ( $a, b$, $\mathrm{c}, \mathrm{d})$, they were packed in plastic bags and stored at pre-determined temperatures $\left(7^{\circ} \mathrm{C}\right.$ and $\left.30^{\circ} \mathrm{C}\right)$, after which they were placed together with those from treatments without pre-hydration $(\mathrm{e}, \mathrm{f}, \mathrm{g})$, at alternating temperatures $\left(20-30^{\circ} \mathrm{C}\right)$ and $8 \mathrm{~h}$ of light (Brasil 2009), until the germination data remained unchanged (15 weeks).

Assessments and germination test data collection followed the same procedures as in the Experiment I. The results were statistically analyzed using a 2 (seeds with and without the outer tegument structure) $\times 3$ (pre-hydration treatments at $7{ }^{\circ} \mathrm{C}$ and $30{ }^{\circ} \mathrm{C}$, and without pre-hydration) factorial scheme, with one additional treatment (seeds without tegument or pre-hydration), in a completely randomized design. The data were transformed from percentage into $\mathrm{y}=\operatorname{arcsen}(x / 100)^{1 / 2}$ and those equal to zero into $y=(x+0.5)^{1 / 2}$ (Pimentel-Gomes 2000). The means were compared using the Tukey test at $5 \%$. The mean of the additional treatment was compared to those from the other treatments using the Dunnett test at $5 \%$.

\section{RESULTS AND DISCUSSION}

For the Experiment I, seed germination was affected by the tested temperatures, with different effects between constant and alternating temperatures (Table 1). At temperatures of $30^{\circ} \mathrm{C}$ and $25{ }^{\circ} \mathrm{C}$, no germination or primary root emission occurred. At $20{ }^{\circ} \mathrm{C}$, just a few seeds emitted the primary root or produced normal seedlings. At $20-30{ }^{\circ} \mathrm{C}, 80 \%$ of the seeds emitted the primary root, $72 \%$ of which resulted in normal seedlings.

After 17 weeks, non-germinated seeds were transferred from constant to alternating temperatures (20-30 ${ }^{\circ} \mathrm{C}$ ), for 19 more weeks, germinating and reaching similar primary root emission and dead seed percentages as seeds kept at $20-30{ }^{\circ} \mathrm{C}$ for the entire test (Table 2). This shows that seeds at constant temperatures were hydrated and largely viable; however, they lacked adequate germinating conditions. As such, it is important to alternate the temperature during $B$. chinensis germination (Qin et al. 2000), as in Iris kaempferi (Sieb.) seeds (Iridaceae), for which the recommended temperature is $20-30{ }^{\circ} \mathrm{C}$ (Brasil 2009). Alternating temperatures are more favorable to germination in some species than maintaining them constant (Marcos-Filho 2005,

Table 1. Average transformed values of primary root emission (RE), germination (G), abnormal seedlings (AS) and non-germinated seeds (NGS) of $B$. chinensis submitted to different germination temperatures over 17 weeks.

\begin{tabular}{cllll}
\hline Temperature & RE $(\%)$ & G $(\%)$ & AS $(\%)$ & NGS $(\%)$ \\
\hline $30^{\circ} \mathrm{C}$ & $0.7(0 \mathrm{c})$ & $0.7(0 \mathrm{c})$ & $0.7(0 \mathrm{~b})$ & $1.25(100 \mathrm{a})$ \\
$25^{\circ} \mathrm{C}$ & $0.7(0 \mathrm{c})$ & $0.7(0 \mathrm{c})$ & $0.7(0 \mathrm{~b})$ & $1.25(100 \mathrm{a})$ \\
$20^{\circ} \mathrm{C}$ & $0.2(4 \mathrm{~b})$ & $0.2(4 \mathrm{~b})$ & $0.7(0 \mathrm{~b})$ & $1.13(96 \mathrm{~b})$ \\
$20-30{ }^{\circ} \mathrm{C}$ & $0.96(80 \mathrm{a})$ & $0.89(72 \mathrm{a})$ & $0.28(8 \mathrm{a})$ & $0.44(20 \mathrm{c})$ \\
\hline $\mathrm{CV}(\%)$ & 10.77 & 15.61 & 23.22 & 2.63 \\
\hline
\end{tabular}

* Means followed by the same letter in the column do not differ according to the Tukey test at $5 \%$. Values followed by letters between parentheses show the original means.

Table 2. Average transformed data for primary root emission (RE), germination (G), abnormal seedlings (AS), dead seeds (DS), primary root emission speed index (RESI), germination speed index (GSI) and average primary root emission time (RET) and germination time (GT) of $B$. chinensis seeds, following the transfer to alternating temperatures $\left(20-30^{\circ} \mathrm{C}\right)$ for 19 weeks, after remaining at constant temperatures $\left(20^{\circ} \mathrm{C}, 25^{\circ} \mathrm{C}\right.$ and $\left.30^{\circ} \mathrm{C}\right)(17$ weeks), compared to the control kept at alternating temperatures $\left(20-30^{\circ} \mathrm{C}\right)(17$ weeks).

\begin{tabular}{ccccccccc}
\hline Temperature & RE (\%) & G (\%) & AS (\%) & DS (\%) & RESI & GSI & RET & GT \\
\hline $30{ }^{\circ} \mathrm{C}$ & $0.95(78 \mathrm{a})$ & $0.93(76 \mathrm{a})$ & $0.14(2 \mathrm{~b})$ & $0.47(22 \mathrm{a})$ & $0.36(12.97 \mathrm{a})$ & $0.31(9.34 \mathrm{a})$ & $0.18(3.31 \mathrm{a})$ & $0.21(4.25 \mathrm{a})$ \\
$25^{\circ} \mathrm{C}$ & $0.94(77 \mathrm{a})$ & $0.93(76 \mathrm{a})$ & $0.10(1 \mathrm{~b})$ & $0.48(23 \mathrm{a})$ & $0.31(9.54 \mathrm{~b})$ & $0.28(8.10 \mathrm{a})$ & $0.21(4.51 \mathrm{~b})$ & $0.23(5.22 \mathrm{~b})$ \\
$20^{\circ} \mathrm{C}$ & $0.98(82 \mathrm{a})$ & $0.96(80 \mathrm{a})$ & $0.14(2 \mathrm{~b})$ & $0.43(18 \mathrm{a})$ & $0.21(4.22 \mathrm{c})$ & $0.19(3.74 \mathrm{~b})$ & $0.31(9.81 \mathrm{c})$ & $0.33(11.09 \mathrm{c})$ \\
$20-30{ }^{\circ} \mathrm{C}$ & $0.96(80 \mathrm{a})$ & $0.90(72 \mathrm{a})$ & $0.06(8 \mathrm{a})$ & $0.45(20 \mathrm{a})$ & $0.22(4.92 \mathrm{c})$ & $0.19(3.69 \mathrm{~b})$ & $0.30(9.20 \mathrm{c})$ & $0.32(10.46 \mathrm{c})$ \\
\hline $\mathrm{CV}(\%)$ & 5.02 & 5.02 & 32.22 & 10.51 & 14.55 & 11.44 & 7.85 & 5.79 \\
\hline
\end{tabular}

* Means followed by the same letter in the column do not differ using the Tukey test at $5 \%$. Values followed by letters between parentheses show the originals means. 
Dousseau et al. 2011, Baskin \& Baskin 2014, Zucareli et al. 2015, Gomes et al. 2016).

The presence of light $(8 \mathrm{~h})$ in the alternating temperature condition was likely not responsible for the onset of the germination process, since the substrate used (paper roll) is not recommended for light-sensitive seeds (Brasil 2009). Moreover, the recommended special precautions to prevent ambient light from affecting the seeds (Baskin \& Baskin 2014) were not taken during weekly counting.

The seeds transferred from constant to alternating temperatures exhibited a higher primary root emission and germination speed than those kept at $20-30{ }^{\circ} \mathrm{C}$ for the entire test. Differences in speeds were detected by the average speed and time indices for primary root emission and germination (Table 2), with a marked effect of the temperature prior to seed transfer. The best results were obtained with seeds hydrated at $30{ }^{\circ} \mathrm{C}$, in which primary root emission and germination speed indices were at least twice as high, if compared to a slower germination (Table 2).

To interpret these results, the initial phase of the Experiment I, with seeds kept at different constant temperatures for germination and alternating temperatures (during the entire test), may be considered a phase that promoted pre-hydration and, after being transferred to alternating temperatures, as the effective phase to assess germination. Under this interpretation, pre-hydration exerted a physiological conditioning effect (hydroconditioning), since it caused an increase in the germination speed (germination speed index, primary root emission speed index and mean germination time) (Table 2) and a possible action to overcome dormancy (MarcosFilho 2005, Costa et al. 2013, Medeiros et al. 2015, Bisognin et al. 2016). There are reports of positive effects of pre-treating $B$. chinensis seeds to overcome dormancy in a moistened substrate at temperatures varying between $5{ }^{\circ} \mathrm{C}$ and $30{ }^{\circ} \mathrm{C}$ (Padua et al. 1999 , Qin et al. 2000).

For the Experiment II, the treatments in the presence and absence of an outer tegument structure combined with those involving pre-hydration of $B$. chinensis seeds independently affected the variables, except for the interaction between average germination time and the effects obtained by analysis of variance (Tables 3 and 4).

The percentages of primary root emission, germination, abnormal seedlings and dead seeds were similar for seeds with or without the outer tegument structure (Table 3). The control, a naked seed (no tegument), did not differ from the other treatments, in terms of primary root emission and dead seed percentage (Table 3 ). The lower germination percentage exhibited by the control seeds was possibly due to the method used for removing the inner tegument structure (with a razor blade), which likely injured the reserve tissues and the embryo, resulting in a greater seedling abnormality (Table 3 ). On the other hand, injury to the embryo does not always cause abnormal seedlings (Martins et al. 2012). Thus, further studies are needed to devise a technique to remove the seed tegument without causing damage and to determine whether removing this structure may interfere in the formation of normal seedlings.

Differences were detected in the primary root emission and germination speeds between tegument removal treatments (Table 4). Seeds with an outer tegument structure (whole seeds) displayed a lower primary root emission speed, resulting in a lower speed index and a longer average germination time than seeds with no outer tegument structure (Table 4). Mendes et al. (2009), Martins et al. (2012) and Silva et al. (2014) support the idea that the presence of structures such as the seed tegument and pericarp cause a delay in seed hydration during the germination process. As such, the protective outer tegument structure of $B$. chinensis seeds may delay hydration and primary root emission.

The germination speed index and average germination time were also lower in seeds with outer tegument structure (Table 4). The difference between naked seeds and those with an outer structure was evident by the average germination time in the treatment without pre-hydration (Table 4), and a consequence of the effect observed on primary root emission speed. In Ricinus communis L. seeds, removing the seed tegument caused an increase in the germination percentage and speed (Mendes et al. 2009).

The pre-hydration treatments affected the germination and abnormal seedling percentages, resulting in lower germination and higher abnormal seedling values for seeds with no pre-hydration (Table 3). As such, pre-hydration showed a positive effect on germination, i.e., seedling formation, without affecting the primary root emission and dead seed percentages (Table 3 ).

Pre-hydrated seeds exhibited shorter average primary root emission times and primary root emission speed indexes (Table 4), which must have 
Table 3. Average transformed data for primary root emission, germination, abnormal seedlings and dead seeds of B. chinensis submitted to pre-hydration (at $7{ }^{\circ} \mathrm{C}, 30^{\circ} \mathrm{C}$ and without pre-hydration), combined with the removal of the outer tegument structure (ROT) or not (outer tegument intact structure - OT) and an additional control sample of seeds without tegument or pre-hydration.

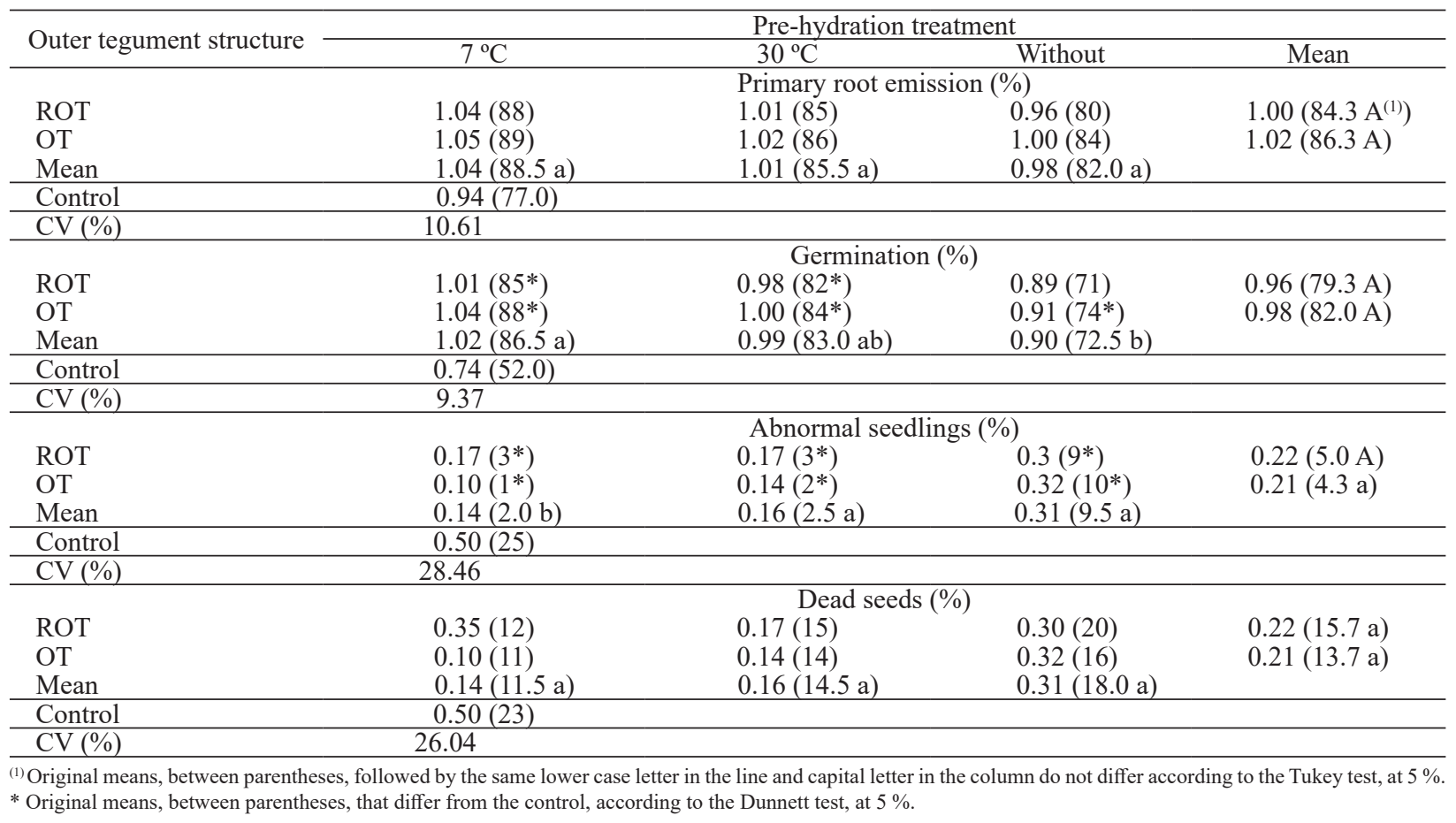

Table 4. Average transformed values for primary root emission speed index (RESI), germination speed index (GSI), mean primary root emission time (RET) and mean germination time (GT) of B. chinensis seeds submitted to pre-hydration treatments (at $7{ }^{\circ} \mathrm{C}, 30^{\circ} \mathrm{C}$ and without pre-hydration) combined with removal (ROT) or not of the outer tegument structure (OT) and control seeds with no tegument or pre-hydration.

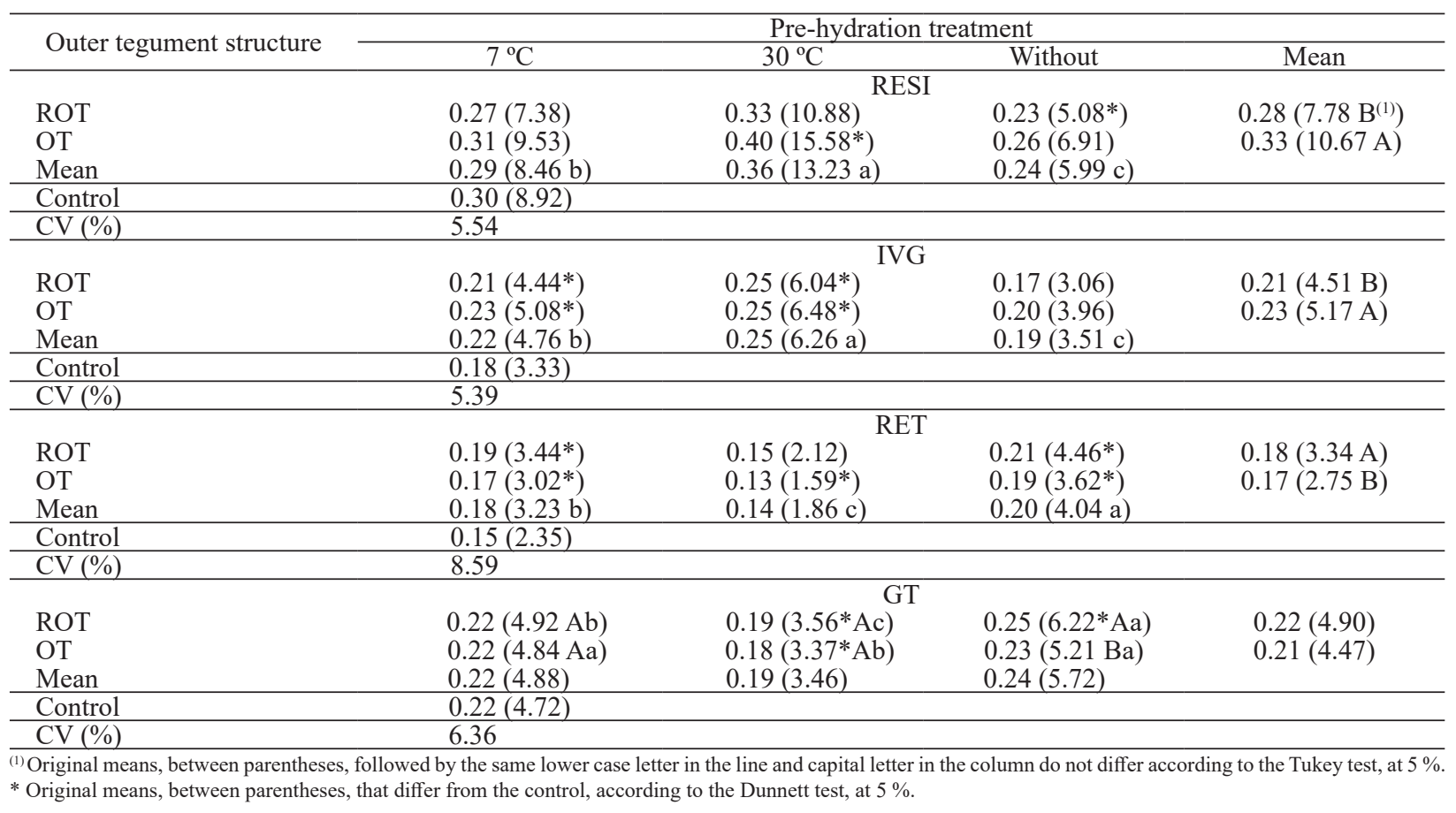


allowed a normal seedling formation even for the less vigorous seeds, resulting in an increase in the germination percentage (Table 3). By contrast, the delayed primary root emission in seeds with no pre-hydration means they may expend more energy (reserves) in the process, thereby compromising the formation and growth of seedlings, which may provoke an increase in the number of abnormal seedlings (Table 3 ).

Different effects between pre-hydration temperatures $\left(7{ }^{\circ} \mathrm{C}\right.$ and $\left.30{ }^{\circ} \mathrm{C}\right)$ were detected in primary root emission and germination speeds, with $30^{\circ} \mathrm{C}$ exhibiting the highest indices and lowest average times (Table 4).

A pre-hydration temperature of $7^{\circ} \mathrm{C}$ was the precooling temperature (stratification) used to overcome dormancy, as it is recommended for other species of Iridaceae, such as Freesia refracta (Jacq.) and Iris kaempferi (Brasil 2009), and there were favorable effects for B. chinenesis seeds (Padua et al. 1999).

An overall analysis shows that combining the outer tegument structure removal and pre-hydration at $30^{\circ} \mathrm{C}$ caused an increase in both primary root emission and germination speed. It is important to underscore this result, since a gain in germination speed is what is most desired in seeds with slow germination and/or dormancy.

The experiment demonstrates that removing the outer tegument structure followed by prehydrating the seeds at $30^{\circ} \mathrm{C}$, for three weeks, and germinating at alternating temperatures between $20{ }^{\circ} \mathrm{C}$ and $30^{\circ} \mathrm{C}$, with light $(8 \mathrm{~h})$, are promising procedures to ensure a successful germination in $B$. chinensis seeds.

\section{CONCLUSIONS}

1. Removing the outer tegument structure and pre-hydrating seeds at $30{ }^{\circ} \mathrm{C}$, for three weeks, accelerates the germination process of $B$. chinensis seeds;

2. Alternating temperatures $\left(20-30{ }^{\circ} \mathrm{C}\right)$ with light $(8 \mathrm{~h})$ accelerates the germination process of B. chinensis seeds.

\section{ACKNOWLEDGMENTS}

To the Fundação de Amparo à Pesquisa do Estado de São Paulo (FAPESP), for the scholarship granted to the authors, and the laboratory technician Valeria Cristina R. Giandoni, for helping during the analyses.

\section{REFERENCES}

BASKIN, J. M.; BASKIN, C. C. Seeds: ecology, biogeography, and evolution of dormancy and germination. Cambridge: Cambridge University Press, 2014.

BEWLEY, J. D. et al. Seeds: physiology of development, germination and dormancy. London: Springer Science \& Business Media, 2012.

BISOGNIN, M. B. et al. Desempenho fisiológico de sementes olerícolas em diferentes tempos de hidrocondicionamento. Revista de Ciências Agrárias, v. 39, n. 3, p. 349-359, 2016.

BRASIL. Ministério da Agricultura, Pecuária e Abastecimento. Regras para análise de sementes. Brasília, DF: MAPA/ACS, 2009.

COSTA, D. S. et al. Incidence of storage fungi and hydropriming on soybean seeds. Journal of Seed Science, v. 35, n. 1, p. 35-41, 2013.

DOUSSEAU, S. et al. Ecofisiologia da germinação de sementes de Campomanesia pubescens. Ciência Rural, v. 41, n. 8 , p. $1362-1368,2011$.

GOMES, J. P. et al. Substratos e temperaturas para teste de germinação em sementes de Myrtaceae. Ciência Florestal, v. 26, n. 1, p. 285-293, 2016.

LORENZI, H.; SOUZA, H. M. Plantas ornamentais no Brasil: arbustivas, herbáceas e trepadeiras. 3. ed. Nova Odessa: Plantarum, 2001.

MAGUIRE, J. D. Speed of germination: aid in selection and evaluation for seedling emergence and vigor. Crop Science, v. 2, n. 2, p. 176-177, 1962.

MARCOS-FILHO, J. Fisiologia de sementes de plantas cultivadas. Piracicaba: ESALQ, 2005.

MARTINS, L. et al. Influence of pre-germination treatments and temperature on the germination of crambe seeds (Crambe abyssinica Hochst). Idesia (Arica), v. 30, n. 3, p. 23-28, 2012.

MEDEIROS, M. A. et al. Hidrocondicionamento e armazenamento de sementes de melão. Semina: Ciências Agrárias, v. 36, n. 1, p. 57-66, 2015.

MENDES, R. de C. et al. Tratamentos pré-germinativos em sementes de mamona (Ricinus communis L.). Revista Brasileira de Sementes, v. 31, n. 1, p. 187-194, 2009.

PADUA, L. S. de; BUNYAPRAPHATSARA, N.; LEMMENS, R. H. M. J. Plant resources of south-east 
Asia. 1999. Available at: <http://www.proseanet.org>. Access on: 01 Nov., 2016.

PIMENTEL-GOMES, F. Curso de estatística experimental. 14. ed. Piracicaba: ESALQ/USP, 2000.

QIN, M. et al. Studies on germination of seeds of Belamcanda chinensis (D) DC. influenced by temperature. Plant Science Journal, v. 30, n. 2, p. 151-156, 2000.

SANTANA, D. G; RANAL, M. A. Análise estatística na germinação. Revista Brasileira de Fisiologia Vegetal, v. 12, n. 4, p. 205-237, 2000.

SILVA, R. C. et al. Técnicas para superação da dormência de sementes de guanandi. Pesquisa Agropecuária Brasileira, v. 49, n. 9, p. 719-727, 2014.

VITALI, M. D. J. et al. Entomofauna visitante de Belamcanda chinensis (L.) DC (Iridaceae) durante o período de floração. Revista Brasileira de Zoologia, v. 12, n. 2, p. 239-250, 1995.

XIN, R. H. et al. Belamcanda chinensis (L.) DC: ethnopharmacology, phytochemistry and pharmacology of an important traditional Chinese medicine. African Journal of Traditional, Complementary and Alternative Medicines, v. 12, n. 6, p. 39-70, 2015.

ZHANG, L. et al. Belamcanda chinensis (L.) DC: an ethnopharmacological, phytochemical and pharmacological review. Journal of Ethnopharmacology, v. 186, n. 1, p. 1-13, 2016.

ZHANG, Y. et al. Anti-osteoporotic effects of medicinal herbs and their mechanisms of action. Asian Journal of Traditional Medicines, v. 1, n. 3, p. 1-7, 2006.

ZUCARELI, V. et al. Influence of light and temperature on the germination of Passiflora incarnata L. seeds. Journal of Seed Science, v. 37, n. 2, p. 162-167, 2015. 